\title{
Priprema čitača za navještaj Božje riječi
}

\author{
Zvonko PAŽIN* \\ - https://doi.org/10.31823/d.27.3.7 • \\ UDK: 27-282-722.541 • Pregledni članak \\ Primljeno: 28. rujna 2018. • Prihvaćeno: 9. rujna 2019.
}

* Prof. dr. sc.

Zvonko Pažin, Katolički bogoslovni

fakultet u Đakovu Sveučilišta Josipa Jurja Strossmayera u Osijeku,

P. Preradovića 17, p. p. 54, Đakovo, Hrvatska, zvonko.pazin@os.t-com.hr

Sažetak: U prvom dijelu autor ističe kako je navještaj Božje riječi sastavan dio bogoslužja u kojem se riječ i čin otajstveno ostvaruju. Zato je u Crkvi od početaka bila ustrojena služba čitača. Tijekom stoljeća tu su službu preuzeli zaređeni službenici. Nakon liturgijske reforme - s pojavom narodnoga jezika u bogoslužju - ponovno se uvode čitači. Autor zatim govori o daljnjoj i bližoj pripravi čitača za navještaj Božje riječi u bogoslužju. Daljnja priprava sastojala bi se od teološko-liturgijskih elemenata te od praktičnih vježbi čitanja. Predlaže se neakademski način priprave koji bi se sastojao od seminara $i$ vježbi na osnovu pripravljenih materijala, što bi redovito bilo na nadžupnoj razini. Bliža priprava bila bi tjedni sastanak čitača $u$ kojem bi se dao egzegetski uvod u pojedino citanje, nakon čega bi slijedila vježba čitanja prema određenim pravilima. $\mathrm{Na}$ koncu autor problematizira neriješena pitanja u općoj $\mathrm{Cr}$ kvi glede postavljenih (institucionalnih) službi čitača i čitača privremenim odabirom, (temporanea deputatione) jer se, $u$ praksi, $u$ institucionalnu službu čitača $u$ nas redovito uvode samo kandidati za svećeništvo, dok su - pravno gledajući - čitači privremenim odabirom osobe koje godinama obavljaju tu službu.

Ključne riječi: navještaj Božje riječi, liturgijski čitači, euharistija, priprava za navještaj Božje riječi, službe temporanea deputatione.

\section{Uvod}

Božja riječ naviještena u bogoslužju živi je Božji govor svomu narodu, ona je Božji glas koji se uprisutnjuje u tu odre- 
đenu zajednicu koja hodi prema spasenju. Zato je - prije svakoga govora o načinu i tehnici čitanja, kao i o načinu priprave za čitanje - silno važno naglasiti upravo tu životnost i životvornost Božje riječi, gdje Bog ovdje i sada progovara svome puku.

Zato ću u prvom dijelu prikazati smisao i važnost naviještanja Božje riječi u bogoslužju, kao i u službi čitača kroz povijest. Nakon toga bit će riječi o daljnjoj i bližoj pripravi za navještaj Božje riječi. Na koncu je dodatak gdje se obrađuju neka otvorena pitanja glede službe liturgijskih čitača.

\section{Božja riječ u bogoslužju}

Nije isto pred publikom kazivati stihove Antuna Gustava Matoša i navijestiti Božju riječ u bogoslužju. Kazivati stihove velikoga pjesnika za dobroga kazivača ili glumca znači prenijeti i sadržaj i emociju i poruku koju taj veliki pjesnik govori, na primjer u svom prekrasnom sonetu Notturno. To, naravno, nije lako. Kazivač ili glumac treba biti vrstan. Međutim za navještaj Božje riječi traži se sve to spomenuto, ali još nešto i više. Božja riječ ne prenosi samo govor, poruku i emociju koju je nekoć htio izraziti biblijski pisac. Naviještanje Božje riječi u bogoslužju jest uprisutnjenje i ponazočenje onoga istoga živoga govora koji su mogli slušati suvremenici. Međutim navještaj Božje riječi u isto je vrijeme živa riječ koju Bog sada upućuje svome narodu. Sveto pismo za nas je uvijek Božja riječ, bez obzira na to tko je, kada i na koji način zapisao zadnju redakciju.

Prisjetimo se da je osnovni smisao Božje riječi upravo taj da bude naviještena Božjem narodu. To je u početku moglo izgledati kao nužnost: knjige su bile skupe, rukom pisane, tako da su se i svetopisamski svitci ponajčešće nalazili samo u hramu ili u sinagogama, vrlo rijetko u privatnom vlasništvu. Zato ljudi uglavnom nisu privatno čitali Božju riječ, nego su slušali navještaj te riječi u bogoslužju, u zajednici vjernika. Prisjetimo se naviještanja Božje riječi povratnicima iz sužanjstva:

»Svećenik Ezra donese Zakon pred zbor ljudi, žena ${ }^{1}$ i sviju koji su bili sposobni da ga razumiju. Na trgu koji je pred Vodenim vratima počeo je čitati knjigu, od ranoga jutra do podneva, pred ljudima, ženama i pred onima koji su bili zreli. Sav je narod pozorno slušao knjigu Zakona.« (Neh 8, 2-3)

Znamo da su poslije sužanjstva posvuda u Palestini i u dijaspori nicale sinagoge, gdje se svake subote čitalo Pismo i to tako da se kroz tri godine pročitala hebrejska Biblija.

\footnotetext{
${ }^{1}$ Za razliku od našega službenoga prijevoda, u nekim drugim prijevodima govori se $\mathrm{i} \gg$ muževima i ženama «. Npr. na tome mjestu njemački prijevod glasi »Männer und Frauen «, a slovenski »moži in žene $\ll$.
} 
Od samih početaka i u euharistiji se naviještala riječ. Djela apostolska svjedoče kako je Pavao prije nego što je razlomio kruh govorio, to jest nije doslovno čitao dijelove Staroga zavjeta:

$\gg$ U prvi dan tjedna, kad se sabrasmo lomiti kruh, Pavao im govoraše i, kako je sutradan kanio otputovati, probesjedi sve do ponoći. (...) Pošto razlomi kruh i blagova, dugo je još zborio, sve do zore.« (Dj 20, 7.11)

Međutim već oko 150. godine u svojoj Apologiji Justin svjedoči o naviještanju Božje riječi u sklopu euharistijske gozbe:

$\gg$ A u dan zvan dan sunca drži se zajednički sastanak svih, bilo da borave u gradu ili na selu. Koliko već ima vremena, čitaju se spomen-zapisi apostolâ $\mathrm{i}$ knjige proročke. ${ }^{2}$

\subsection{VAŽNOST BOŽJE RIJEČI}

Pismo za sebe kaže: »Živa je Riječ Božja i djelotvorna « (Heb 4, 12). Od početaka je tako u ekonomiji spasenja. Božja riječ »Neka bude « rezultirala je činom - stvaranjem. Isus je uzetome rekao: »Ustani, uzmi nosiljku i pođi kući!« i uzeti je čovjek zaista ustao i uzeo svoju nosiljku (Mt 9, 6). Isus je rekao: »Uzmite i jedite! Ovo je tijelo moje! « i tako je bilo.

Životvornost Božje riječi očituje se i danas jer se u svakom bogoslužju ostvaruje djelo spasenja. Ono što se u sakramentalnoj liturgiji ostvaruje, to je prethodno naviješteno u bogoslužju riječi. Tako npr. u bogoslužju riječi prvo nam bude naviještena Isusova riječ koja govori: $\gg$ Tko se ne rodi nanovo, odozgor, ne može vidjeti kraljevstva Božjega! (...) Ako se tko ne rodi iz vode i Duha, ne može ući u kraljevstvo Božje « (Iv 3, 3-4), a onda slijedi sam čin krštenja, gdje se ta naviještena riječ otajstveno ostvaruje. Tako je riječ bitno povezana sa samim liturgijskim znakom ili činom u užem smislu, kako to kaže Augustin: »Accedit verbum ad elementum, et fit sacramentum $\ll$, tj. $\gg$ Tvarnoj osnovi pridolazi riječ, i nastaje sakrament $\ll .^{3}{ }^{3}$ Sto je u riječi naviješteno, to se po sakramentalnom znaku u bogoslužju i ostvaruje. Oba su ta dijela bogoslužja važna. ${ }^{4}$ Ako je bitno da u krštenju bude sve valjano, jednako

\footnotetext{
${ }^{2}$ Apologie pour les chrétiens de Justin, br. 66, u: Collection Sources chrétiennes, br. 507. Usp. također: A. HÄNGGI, I. PAHL (prir.), Prex eucharistica. Textus e variis liturgiis antiquioribus selecti, Fribourg, 1968., 69-71., 2006., Prijevod preuzet iz: Božanski časoslov obnovljen prema odluci ekumenskog sabora II. vatikanskog a proglašen vlašću pape Pavla VI. Časoslov rimskog obreda, II, Zagreb, 1984., 510. Vidi još: JUSTIN, Apologije, Split, 2012., 105.

${ }^{3}$ In Evangelium Johannis tractatus, 80, 3. Citirano prema: Katekizam Katolicke crkve, Zagreb, 1994., br. 1228, bilj. 28.

${ }^{4}$ Slična je i židovska teologija pashalne večere. Na početku najmlađi član pita starije zašto je ta večer drukčija od ostalih. Nato najstariji član počinje dugu pripovijest - Hagadu - gdje potanko opisuje
} 
je važno da i Božja riječ bude dobro naviještena. ${ }^{5}$ Navještaj Božje riječi osobito je važan u euharistijskom slavlju. Opća uredba Rimskog misala kaže:

»Misa se na neki način sastoji od dvaju dijelova: od liturgije riječi i euharistijske liturgije, koji su tako međusobno povezani da tvore jedan bogoštovni čin. U misi se, naime, pripravlja kako stol Božje riječi tako i Kristova tijela, s kojeg vjernici primaju pouku i okrjepu. $\ll^{6}$

Kao što je već rečeno, Sveto je pismo oduvijek bilo namijenjeno ponajprije naviještanju u bogoslužju, baš kao što je kazališno djelo namijenjeno kazališnom uprizorenju, a ne ponajprije individualnom čitanju.

Biskupska sinoda o Božjoj riječi u životu i poslanju Crkve od 5. do 26. listopada 2008. godine jasno govori da je bogoslužje privilegiran prostor Božje riječi te da se ta ista Božja riječ u bogoslužju i naviješta i ostvaruje:

»Sinodski oci naglašavaju kako je liturgija privilegirani prostor u kojem se Božja riječ u punini izražava, bilo u slavlju sakramenata, bilo osobito u euharistiji, bilo u bogoslužju časova ili u liturgijskoj godini. Otajstvo spasenja pripovijedano u Svetome pismu nalazi u liturgiji vlastito mjesto u kojem se ono naviješta, sluša i ostvaruje. $\ll^{7}$

Slično govori i novi Lekcionar:

»Mnogovrsno blago jedne te iste riječi Božje čudesno dolazi do izražaja u različitim slavljima kao i u različitim vjerničkim skupovima koji u slavlju sudjeluju, bilo da se tijekom godine slavi spomen Kristova otajstva u svojem vremenskom odvijanju, bilo da se slave sakramenti i sakramentali Crkve, bilo kad pojedini vjernici odgovaraju nutarnjem djelovanju Duha Svetoga. Tada naime samo liturgijsko slavlje, što se najtješnje prislanja uz Božju riječ i od

kako ih je Bog izveo iz Egipta i kako im je naredio slaviti Pashu u obrednoj večeri. Nakon toga slijedi sama večera. Usp. K. DA-DON, Židovstvo. Život, teologija i filozofija, Zagreb, 2004., 183. Usp. također: O. CARENA, Cena pasquale ebraica per comunità cristiane, Casale Monferrato, 1980., 21.

${ }^{5}$ Usp. Z. PAŽIN, Liturgijsko-teološko utemeljenje homilije, u: Diacovensia 18(2010.)3, 517-535., osobito: 519-521.

${ }^{6}$ Rimski misal prerađen prema odluci svetog ekumenskog sabora Drugog vatikanskog, objavljen vlašću pape Pavla VI, preuređen brigom pape Ivana Pavla II. Opća uredba iz trećeg tipskog izdanja, Zagreb, 2004., br. 28. Opća se uredba u tome tekstu poziva na SC 56 koji to isto izražava gotovo istim riječima: »Dva dijela od kojih se misa sastoji, naime, bogoslužje riječi i euharistijsko bogoslužje, tako su usko među sobom povezana, da tvore jedan bogoštovni čin.«

${ }^{7}$ Konačni popis propozicija koje su na završetku sinode biskupi dali papi na razmatranje, propozicija br. 14. Dostupno na: http://www.vatican.va/roman_curia/synod/documents/rc_synod_doc_ 20081025_elenco-prop-finali_it.html (13.8.2018.). 
nje dobiva snagu, postaje novim događajem, a ta se riječ obogaćuje novim tumačenjem i djelotvornošću. Tako u liturgiji Crkva vjerno slijedi onaj način čitanja i tumačenja Svetoga pisma kojemu je pribjegavao sam Krist, koji je polazeći od 'danas' svojega događaja poticao produbljivanje svih pisama. $\ll^{8}$

Dakle liturgijsko slavlje dobiva snagu od Božje riječi, koja se obogaćuje tumačenjem. Konačno, po Božjoj se riječi i sakramentalnim znakovima u bogoslužju posadašnjuje Kristovo spasenje.

\subsection{SLUŽBA ČITAČA KROZ POVIJEST}

Dok u službi sinagoge, bar načelno, svaki odrastao muškarac može i smije čitati Božju riječ, ${ }^{9}$ čini se da se u Crkvi vrlo rano - od samih početaka - ustrojila lektorska služba. ${ }^{10}$ Spominje se već oko 150 . godine u Justinovoj Apologiji. Službu čitača spominju Tertulijan i Ciprijan. Hipolit Rimski u Apostolskoj predaji (početak 3. st.) izrijekom spominje da lektora biskup postavlja u službu, ali bez polaganja ruku. ${ }^{11}$ Zanimljivo je da su čitači redovito bili mlađe dobi, često dječaci. Smatra se da je to iz dvaju razloga. Prvo, dječački je glas jasan i dobro se može čuti u prostranim bazilikama, a dugo, smatralo se da su oni zbog svoje nevinosti - primjerene toj dobi - osobito prikladni naviještati Božju riječ. Pa i oni koji su u starijoj dobi čitali naglašavali su da su čitači od svoje prve mladosti. Svaka je Crkva imala više čitača, a oni su zacijelo bili posebno pripravljani i poučavani za tu službu, kako je to u Rimu zasvjedočeno sredinom 4. st. Tako će naš mučenik Polion iz Cibalâ (Vinkovaca) na pitanje upravitelja Proba čime se bavi odgovoriti: »Predstojnik sam lektora.« Na pitanje: »Kojih lektora? « Polion će reći: »Onih koji običavaju puku čitati Božju riječ. $\ll{ }^{12} U$ početcima su lektori čitali sva čitanja, uključujući i evanđelja, kako to svjedoči Ciprijan. Međutim već od vremena sv. Jeronima čitanje evanđeoskih odlomaka bilo je pridržano đakonima. Već od 6. st. subđakoni preuzimaju čitanja, tako da služba lektora praktički nestaje. Mladići koji su prije bili lektori sada prelaze u schola cantorum. Od toga vremena lektorat je uvršten u niže redove, ali bez ikakve praktične važnosti. Bio je to isključivo prijelazni stupanj do prezbiterskoga ređenja.

\footnotetext{
${ }^{8}$ Lekcionar I. Nedjelje ABC i svetkovine Gospodnje. Prethodne napomene I., Zagreb, 2007., br. 3.

${ }^{9}$ Prisjetimo se kako je i Isus - po židovskom shvaćanju običan laik - u sinagogi u Nazaretu čitao za vrijeme subotnje službe (usp. Lk 4, 16-20).

${ }^{10}$ Za povijesni pregled te službe (ili nižega reda) usp. M. RIGHETTI, Manuale di storia liturgica, IV, Milano, 1959. (fototipsko izdanje 2005.), 377-380., D. KNIEWALD, Liturgika, Zagreb, 1937., 290., 302.

${ }^{11}$ Usp. La Tradizione apostolica, XI, R. TATEO (prir.), 1979. 73.

${ }^{12}$ Z. PAŽIN, K. VIŠATICKI, Vlastiti misal Đakovačke i Srijemske biskupije, Đakovo, 2013., 151.
} 
Tako čitanje misnih čitanja - rezervirano za subđakone i đakone - postaje isključivo klerička služba.

\section{Bliža i daljnja priprema čitača za navještaj Božje riječi}

Da bi čitanje/naviještanje bilo kvalitetno, temeljna je pretpostavka da čitač treba razumjeti tekst koji čita. ${ }^{13}$ Zamislite na primjer da netko tko nije studirao medicinu na jednom stručnom skupu pročita stručni medicinski esej. Bi li on to mogao dobro pročitati? Ne. Očito je. Da bi se neki tekst valjano pročitao/navijestio, nužno je da čitač razumije ono što čita. Za to je i za naviještanje riječi u bogoslužju potrebna daljnja i bliža priprava.

\subsection{DALJNJA PRIPRAVA}

Čitač bi trebao steći osnovnu biblijsko-liturgijsku naobrazbu. U nas postoji škola za župne animatore. Međutim teško bi bilo očekivati da svi naši čitači prođu tu školu koja je zahtjevna i traje dvije godine. U svijetu postoje jednostavniji, a ipak učinkoviti modeli koji se uglavnom temelje na dopisnoj teologiji. Evo primjera. Švicarska biskupska konferencija 2000. godine objavila je dokument Smjernice za obučavanje i postavljanje laika u honorarnu/volontersku liturgijsku službu. ${ }^{14} \mathrm{U}$ tom se dokumentu nudi nacrt za izobrazbu čitača na neakademski način: na osnovi ponuđenih materijala održavaju se predavanja i vježbe. Evo osnovnih tema:

- Temeljna znanja o Svetom pismu (postanak, sadržaj, pomoć za razumijevanje)

- Temelji liturgije (teologija liturgije, osnovni elementi, liturgijske službe, značenje riječi i gesta, liturgijska godina)

- Poznavanje reda misnih čitanja (struktura i pravila za izbor čitanja)

- Osnove fonetike i čitanja u javnosti (melodija govora, melodija rečenice, pravilan izgovor)

- Praktične vježbe pred mikrofonom u crkvenom prostoru

- Produbljivanje vlastite biblijsko-liturgijske duhovnosti.

${ }^{13}$ To je osnovni razlog zašto djeca nisu prikladna za naviještanje Božje riječi u bogoslužju. U tome smislu naši biskupi jasno kažu: »Navještaj Božje riječi neka se ne povjerava djeci.« Vidi: HRVATSKA BISKUPSKA KONFERENCIJA, Direktorij za pastoral sakramenata u župnoj zajednici, Zagreb, 2008., br. 95.

${ }^{14}$ Usp. Pastoralschreiben der Schweizer Bischofskonferenz: Leitlinien zur Ausbildung und Beauftragung zu ehren-/nebenamtlichen liturgischen Laiendiensten, Freiburg, 2000. Dostupno na: https://www.liturgie.ch/images/liturgie/liturgiepraxis/dokumente/pdf/sbk_leitlinien_laiendienste.pdf (16. 8. 2018.) 
Predviđeno je da stručne osobe vode čitače u obrađivanju tih materijala, pogotovo kada su u pitanju praktične vježbe. To je po sebi moguće organizirati na dekanatskoj razini, ali bi to - u većim župama - možda bilo moguće i na župnoj razini. Za naše prilike rekli bismo da daljnja priprava treba sadržavati teološke (liturgijske) sadržaje te teoriju i praksu naviještanja Božje riječi u bogoslužju.

\section{a) Teološko-liturgijski sadržaji}

Potrebno je za cijelu nadbiskupiju pripraviti materijale koji će obrađivati osnove teološko-liturgijske teme važne za službu čitača. To bi uvelike olakšalo zadatak voditelja tečajeva za čitače na (među)župnoj razini. Ti bi materijali mogli biti nalik onima koji su u svoje vrijeme bili pripravljeni za tečajeve priprave za brak, ${ }^{15}$ a sadržavali bi teološko-liturgijski vid, kao i teoriju i praksu čitanja. Razrada teološkoliturgijskih sadržaja zahtijeva mnogo više vremena i prostora. Mi ćemo ovdje više pozornosti posvetiti samom naviještanju Božje riječi.

b) Teorija i praksa čitanja u javnosti, odnosno naviještanja Božje riječi u bogoslužju

Polaznike je važno uvesti u osnovne zakonitosti čitanja u javnosti, odnosno naviještanja Božje riječi. Da bi se tekst dobro pročitao, valja ga učinit svojim, to jest govoriti ga kao vlastitu misao. Dobro je poznavati neka osnovna pravila koja se studiraju i vježbaju na studiju glume. ${ }^{16}$

Za početak je važan uspravan stav tijela: leđa trebaju biti izravnata, grudni koš slobodan, ramena opuštena. Za glumce postoje složene vježbe opuštanja svih mišića, a za čitače će biti važno da, koliko je moguće, budu tjelesno opušteni. Jedna zanimljiva definicija opuštenosti uči nas da nam bude stalo i da nam $u$ isto vrijeme ne bude stalo, to jest čitaču je stalo do toga da se ozbiljno pripravi za čitanje, a kada nastupa, odaje dojam kao da mu nije stalo, to jest opušten je. ${ }^{17}$

Nadalje je također važno naučiti disati iz ošita, u kojem se glas stvara, tako da samo bude upravljan grlom. Kaže autorica: »Kad postignete snagu udaha sve do dna rebara, osobito leđima, te sve do želuca, dok se dijafragma spušta, tada cijelo tijelo postaje dio zvuka, sudjelujući u njemu svojom rezonancijom. $\ll^{18}$ Plitko disanje i forsiranje glasa iz grla dovodi do zamora, povišenih tonova i iritantnoga govorenja.

\footnotetext{
${ }^{15}$ Rastimo u ljubavi. Tečaj priprave za brak, Đakovo, ${ }^{3} 1987$.

${ }^{16}$ Usp. C. BERRY, Glumac i glas, Zagreb, 1977.

${ }^{17}$ Usp. isto, 31.

${ }^{18}$ Usp. isto, 35.
} 
Potrebno je učiti razgovijetno izgovarati teže riječi i suglasničke skupove. U tome smislu ne će baš biti lako razgovijetno pročitati antifonu: $\gg S$ radošću ćete crpsti vodu iz izvora spasenja.« Svećenicima i đakonima isto tako nije lako izgovoriti da će zrno donijeti plod $\gg$ sezdesetorostruk «. Čitanje takvih težih riječi treba posebno vježbati i treba ih sporije izgovarati.

Čitač treba na vrijeme znati kada treba čitati i koje je čitanje toga dana određeno. Jednako tako on treba imati na raspolaganju i biblijski odlomak koji ima čitati. To može biti, naravno, Nedjeljni i blagdanski misal za narod, ${ }^{19}$ a odgovarajuća je čitanja moguće pronaći na različitim mrežnim stranicama. Tako će se čitač moći na miru kod kuće pripraviti. Nitko ne može dobro čitati ako tekst prije toga ne pročita i ne prostudira. To ne čine ni profesionalni glumci. Evo sada najvažnijih korisnih naputaka.

1. Ono što čovjek nije razumio, ne može dobro ni pročitati. Zato se kod kuće treba temeljito pripraviti. Čak ni profesionalci ne mogu dobro pročitati tekst koji ne razumiju. Potrebno je dakle svetopisamski odlomak u sebi čitati dok ga čovjek ne shvati. Naravno, za to je potrebna i određena biblijska kultura. Kako se može provjeriti da sam razumio jedan odlomak? Potrebno je zatvoriti knjigu i pokušati svojim riječima prepričati tekst, odnosno iznijeti njegovu osnovnu poruku. ${ }^{20}$

2. Tko samo u sebi (samo očima) pročita odlomak, u crkvi će zakazati. Tek kad se odlomak naglas pročita, uoče se sve osobitosti i zamke nekoga teksta, kao i njegova ljepota $i$ snaga. Naše su oči brze, ali jezik to često nije: zamuckujemo ili pravimo stanke na krivom mjestu. Dok čitamo samo očima, ne angažiramo glas, ritam disanja, ton, raspoloženje, ne osjeti se dinamika. Zato nije dovoljno spremati se za čitanje samo čitanjem u sebi.

3. Pripremanje nekoga teksta za čitanje započinje time da ga se raščlani. Tako se dobije pregled $i$ čitač postaje sigurnim. Tekst valja prvo pročitati, a zatim ga treba podijeliti na nekoliko smislenih odlomaka, označujući veće pauze između većih odlomaka (npr. //) i kraće pauze između manjih odlomaka (npr. /).

4. Čitati treba sporije nego što bi čovjek činio u običnom razgovoru. Naime čitač ima tekst pred očima i razumije ga. Zato će on i nesvjesno ubrzati čitajući ono što mu je razumljivo. Međutim do vjernika će u crkvi doći samo ono što čuju. K tomu valja imati na pameti da su u crkvi ljudi različite dobi i izobrazbe. Zato su važne stanke. Kada se završi jedan odlomak ili neka važna misao, treba zastati

\footnotetext{
${ }^{19}$ Nedjeljni i blagdanski misal za narod. Godina ABC, Zagreb, 1992.

${ }^{20}$ Usp. R. ZERFASS, Lektorendienst. 15 Regeln für Lektoren und Vorbeter, Leipzig, 1967., R. KLIEM, Der Lektorendienst, Freiburg - Basel - Wien, 1991., P. ANDRIJANIĆ, N. MIHALJEVIĆ (prir.), Čitač. Priručnik za čitače, Donji Andrijevci, 1996.
} 
da ta misao ljudima sjedne i onda nastaviti. Kao što je zdravo sporije jesti i hranu dobro sažvakati, tako je i u naviještanju Božje riječi. K tomu valja čitati dovoljno glasno da mogu čuti i oni slabijega sluha.

5. Zarez zna varati. Nije rečeno da kod svakoga zareza treba i podići glas. Zarez je ponekad uvjetovan pravopisnim pravilima, a ne smislom. Zato treba više gledati na smisao i melodiju rečenice. Na primjer vokativ se od ostalih dijelova rečenice odvaja zarezom, ali ne znači da kod takvoga zareza treba načiniti stanku. Tako ne ćemo izgovoriti:

* $\gg$ Ostani s nama, / Gospodine, / jer zamalo će večer «, nego:

>Ostani s nama, Gospodine, / jer zamalo će večer «,

6. Ponekad se ne treba osvrtati ni na dvotočku i uskličnik ako čitač želi pročitati onako kako govori. Npr. ne ćemo pročitati:

*Petar poče tonuti i kriknu: / »Gospodine, spasi me!« nego:

Petar poče tonuti / i kriknu: »Gospodine, / spasi me! $\ll^{21}$

7. Na koncu rečenice točku treba izgovarati skoro kao zarez. U pjevanju zborovođe naglašavaju da se trebaju izgovoriti svi suglasnici na kraju fraze, tako da se pjeva: $\gg$ Svet, svet, svet «, a ne »Sve, sve, sve «. Slična se pogrješka može dogoditi kod čitanja. Ako čitač na koncu rečenice previše spusti glas, on nesvjesno proguta zadnji slog rečenice i onda se jednostavno ne razumije što je pročitao. Evo primjera:

${ }^{*}$ Ta po Zakonu ja Zakonu umrijeh da Bogu živ im. $_{\text {. }}$ Kristom sam raza $a_{\text {pet. }}$ Živim, ali ne više ja, nego živi u meni $\mathrm{Kri}_{\text {st. }}$

8. Pronaći ispravan naglasak u rečenici nije stvar sreće: $i$ to je rezultat priprave. Svaka kraća misaona cjelina (rečenica ili jedan njezin dio) može imati samo jednu jače naglašenu riječ. Valja imati pred očima da naglasak vrlo rijetko leži na pridjevima, prilozima, niječnim riječima. Osim toga u hrvatskom glagoli imaju posebnu snagu i oni su redovito naglašeni. Nije dobro naglašavati previše riječi, kao u ovom primjeru:

*Ako vi budete opraštali vašim neprijateljima, i vama će Otac moj oprostiti. Bolje bi bilo ovako:

Ako vi budete opraštali vašim neprijateljima, i vama će Otac moj oprostiti.

${ }^{21}$ Takav način čitanja preporuča spomenuti autor: R. ZERFASS. 
Koje bi bile noseće riječi u ovoj rečenici?

Budite slični ljudima koji čekaju svoga gospodara koji se vraća sa svadbe, da mu odmah otvore, čim stigne i pokuca.

Mnogi bi pomislili da su to riječi: ljudima - gospodara - dođe - pokuca otvori. Naprotiv, tekst bi trebalo ovako naglasiti:

Budite slični ljudima koji čekaju svoga gospodara koji se vraća sa svadbe, da mu odmah otvore, čim stigne i pokuca.

9. Melodija rečenice. Nakon što smo odredili ključne ili nosive riječi, važno je uočiti i melodiju rečenice ili fraza da bismo ih mogli naglasiti. To se najbolje prikazuje u napetom luku u kojem razlikujemo rast napetosti, vrhunac i smirenje. Evo dva primjera:

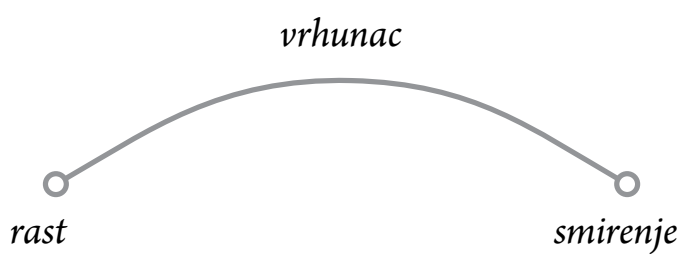

$\gg \mathrm{Za} \quad$ slobodu nas Krist oslobodi! $\ll$

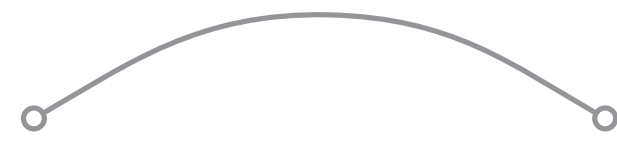

Čovjek se ne opravdava po djelima Zakona, nego

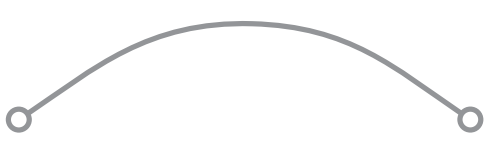

vjerom u Isusa Krista.

10. Ne sluša se samo ušima, nego i očima. Čitač treba obratiti pozornost na način kako hoda, kako stoji, zatim na položaj ruku, na knjigu i na odjeću. U tome smislu nije dobro napadno se odjenuti. Pozornost treba biti stavljena na riječ koju se čita, a ne na čitača. Prije mise potrebno je provjeriti visinu mikrofona. Do ambona treba ići smireno i opušteno. Dok čita, čitač treba stajati na objema nogama. To daje sigurnost i stabilnost.

11. Naš je dah struja koja nosi riječi. Mirno disanje smiruje i samoga čitača i tako mir prenosi i na slušatelje. Tada se brzina čitanja i stanke određuju sami od sebe. Tko ubrzano diše, nužno prebrzo čita. Kada čitač dođe do ambona, treba pričekati koji trenutak dok svi sjednu, smjeste se i obrate pozornost na ambon. Sada dolazi Božja riječ! Čitač treba pogledati te ljude i pomisliti kako oni gladuju za Božjom riječju. Sporo čitati znači polagano čitati i ostaviti vrijeme i za pauze, baš kao u nekom glazbenom komadu. Nakon što se pročita jednu misaonu cjelinu, treba zastati i tako dati vjernicima vremena da riječ uđe u njihove uši i u njihovo srce. 
12. Prije nego što počne čitati tekst, kao i nakon što pročita jednu misaonu cjelinu, čitač treba obuhvatiti pogledom svoje slušatelje, kao što to čine spikeri. To stvara onaj ljudski kontakt kojim se Bog služi da dođe do srca svojih slušatelja. Jednako će učiniti i kod svake veće pauze, tj. na svršetku svakoga pojedinoga odlomka (kako ga je prethodno raščlanio).

13. Nemir i (pretjerano) kašljanje u crkvi često su znak da čitač prebrzo čita i da ga većina ne može slijediti. To je upozorenje da treba usporiti ili eventualno glasnije čitati. Ako je čitanje prebrzo, neartikulirano, vjernici ne mogu ni pratiti ni razumjeti.

14. Čitanje treba započeti vlastitim prirodnim glasom, malo podići glas onda kada se nešto želi naglasiti (prema onoj melodiji rečenice) i opet zaključiti nešto dubljim glasom. Ako čitač počne višim glasom (da se bolje čuje), kod naglašavanja će se početi naprezati i on jednostavno ne će moći izdržati cijelo vrijeme u tome tempu ili će mu grlo početi škripati. Ta se napetost i nervoza onda nužno odražava i na slušatelje. Uz to se onda ne može izbjeći ono ružno pjevanje i pobožno prenemaganje. Potrebno je da čitač, uza sve te pretpostavke, u sebi pronađe svoj prirodni glas te da čita kao da govori vlastite misli.

15. Treba se naučiti služiti pojačalom i mikrofonom. To su redovito vrlo osjetlivi uređaji. Ako se čitač njima nevješto koristi, oni više štete nego što pomažu. Kao prvo, ne treba svaka crkva pojačalo. Neke su dovoljno akustične. Ako već postoji pojačalo, valja iskušati kako mikrofon reagira. Pa i dok čita, sâm čitač može osjetiti stoji li preblizu ili predaleko, je li previše tih ili previše glasan. Ne smijemo ignorirati mikrofon. Zato je važna priprava i u samoj crkvi.

\subsection{BLIŽA PRIPRAVA}

U idealnom slučaju čitači koji čitaju sljedeće nedjelje trebali bi se naći na zajedničkoj pripravi. Susret bi trebala voditi kvalificirana osoba (svećenik, vjeroučitelj). U prvom dijelu voditelj bi trebao dati egzegetski uvod u čitanja, Sitz im Leben, ali i protumačiti određene pojmove koji čitačima nisu jasni, koristeći se postojećom egzegetskom literaturom. Izvrsno pomagalo može biti časopis Služba riječi koji donosi egzegetski uvod u sva nedjeljna čitanja, a može biti koristan i onaj kratki uvod u svako čitanje koji nalazimo u Nedjeljnom i blagdanskom misalu za narod. ${ }^{22}$ U drugom dijelu slijede vježbe čitanja prema izloženim pravilima. Za primjer ćemo uzeti Drugo čitanje jedanaeste nedjelje kroz godinu kruga godine $\gg \mathrm{C} \ll(\mathrm{Gal}$ 2, 16.19-21):

${ }^{22}$ Usp. Nedjeljni i blagdanski misal za narod. Godina ABC, Zagreb, 1992. 
a) Egzegetski kontekst konkretnoga teksta za koji se pripravlja

»Braćo! Znamo: čovjek se ne opravdava po djelima Zakona, nego vjerom $\mathrm{u}$ Isusa Krista. Zato i mi u Krista Isusa povjerovasmo da se opravdamo po vjeri u Krista, a ne po djelima Zakona jer se po djelima Zakona nitko neće opravdati. Ta po Zakonu ja Zakonu umrijeh da Bogu živim. S Kristom sam razapet. Živim, ali ne više ja, nego živi u meni Krist. A što sada živim u tijelu, u vjeri živim u Sina Božjega koji me ljubio i predao samoga sebe za mene. $\mathrm{Ne}$ dokidam milosti Božje! Doista, ako je opravdanje po Zakonu, onda je Krist uzalud umro.«

Ovdje je ključno objasniti kontekst. ${ }^{23}$ Kršćani u Galaciji većinom su bili pogani. Među njima su se pojavili kršćani iz židovstva koji su smatrali da nije dovoljno povjerovati u Isusa Krista i krstiti se, nego da je k tomu potrebno pridržavati se svih židovskih propisa. Galaćani su bili zbunjeni. Pavao im onda iznosi osnove kršćanskoga nauka spasenja. Nitko ne može zaslužiti spasenje i nitko se ne može spasiti samo pridržavanjem židovskih zakona i propisa. Pavao naglašava da smo spašeni besplatno i to smrću i uskrsnućem Kristovim, a ne činjenjem djelâ židovskoga (Mojsijeva) Zakona. Dakle onaj tko prihvati Isusa kao Spasitelja i pokrsti se, spašen je. Neki su kasnije taj Pavlov nauk pojednostavili govoreći da naša djela uopće nisu bitna, nego samo vjera. Međutim nasuprot tomu Pavao na drugom mjestu jasno kaže: »Sto dakle? Da griješimo jer nismo pod Zakonom nego pod milošću? Nipošto!« (Rim 6, 15). Mi smo spašeni besplatno, ali smo onda pozvani i živjeti u skladu s time. Tako Pavao u istoj poslanici jasno kaže da smo spašeni besplatno, da nas je Krist oslobodio robovanja (židovskom) Zakonu, ali da ta sloboda ne bi smjela biti izlikom tijelu da griješimo te da će propasti oni koji čine »djela tijela «: bludnost, nečistoća, razvratnost, itd. (Gal 5, 19-21)

b) Vježba čitanja odlomka koji se ima čitati sljedeće nedjelje

Čitače se pozove da uz pomoć stručnoga voditelja u tekst čitanja stave naglaske na određene riječi pa da onda tekst i pročitaju, nakon čega jedni dugima mogu reći primjedbe. Evo kako se u navedenom tekstu mogu označiti stanke i naglašene riječi, $s$ time da novi redak označava dulju stanku:

\footnotetext{
${ }^{23}$ Osim vrlo korisne Službe riječi, za analizu pojedinih svetopisamskih odlomaka ima mnoštvo literature. Za ovaj odlomak spomenimo samo najpoznatije. C. TOMIĆ, Savao Pavao: vrijeme, život i djelo apostola Pavla, Zagreb, 1982., 129-378., W. J. HARRINGTON, Uvod u Novi zavjet, Zagreb, 1975., 65-74., J. A. FITZMYER, Pavlova teologija, u: R. E. BROWN, J. J. CASTELOT, J. A. FITZMAYER, J. J. KSELMAN, J. J. McKENZIE, D. M. STANLEY, A. SUELZER, B. VAWTER (prir.), Biblijska teologija Starog i Novog zavjeta, Zagreb 1980., 357-434., F. AMIOT, X. LEON-DUFOUR, Djela, u: X. LEON-DUFOUR (ur.), Rječnik biblijske teologije, Zagreb, 1988., 194-200., J. DUPONT, Vjera, u: X. LEON-DUFOUR(ur.), Rječnik biblijske teologije, 1420-1433.
} 
Čitanje Poslanice svetoga Pavla Apostola Galaćanima. //

\section{Braćo! //}

Znamo: / čovjek se ne opravdava po djelima Zakona, / nego vjerom u Isusa Krista. //

Zato i mi u Krista Isusa povjerovasmo / da se opravdamo po vjeri u Krista, / a ne po djelima Zakona / jer se po djelima Zakona nitko neće opravdati. // Ta po Zakonu ja Zakonu umrijeh / da Bogu živim. S Kristom sam razapet. //

Živim, / ali ne više ja, / nego živi u meni Krist. / / A što sada živim u tijelu, / u vjeri živim u Sina Božjega / koji me ljubio / i predao samoga sebe za mene. //

Ne dokidam milosti Božje! / Doista, ako je opravdanje po Zakonu, / onda je Krist uzalud umro. //

Riječ Gospodnja.

I ovdje se može - radi vježbe - označiti i lukove naglašavanja.

\subsection{NeRIJEŠEnA PITANJA}

U apostolskom pismu Ministeria quaedam iz 1972. godine Pavao VI. određuje da se, umjesto dotadašnjih nižih redova, uvedu službe lektora i akolite. ${ }^{24}$ Određeno je da se te službe kao trajne mogu podjeljivati i laicima, ne nužno onima koji teže đakonatu ili prezbiteratu. Nadalje se u br. VII. precizira: »Prema časnoj predaji Crkve, ustanova čitača i akolita pridržana je za muškarce.«

U praksi se ipak vrlo rijetko događa da laici budu postavljeni u te dvije službe. Osim kandidata za svećeništvo u nas se veoma rijetko netko postavlja u službu lektora ili akolite. Vjerojatno župnicima predstavlja poteškoću predložiti nekoga za tu službu jer su u tome slučaju isključene žene koje već godinama obavljaju službu čitača češće nego muškarci) ili službu izvanrednoga djelitelja pričesti. Osim toga ne postoji neki program ili naputak na razini nadbiskupije koji bi određivao tko bi mogao biti uveden u tu službu te kakvu bi pripravu trebao proći. Naša biskupijska sinoda go-

${ }^{24}$ Usp. Rimski pontifikal obnovljen prema odluci svetog ekumenskog sabora Drugog vatikanskog a proglašen vlašću pape Pavla VI. službe u Crkvi. Ređenja. Posvete. Zavjetovanja, Zagreb, 1988., 8-10. 
vori samo da bi se trebao u tome smislu stvoriti neki sustav, ali ne donosi konkretne odredbe. ${ }^{25}$

Čini se da je pokoncilska Crkva u tome pošla u dvama različitim smjerovima od kojih je svaki na svoj način nedostatan i nedorečen. Prvo, uvedene su dvije postavljene službe otvorene laicima (lektorat i akolitat) koje u praksi nisu zaživjele ili jedva da su zaživjele. $S$ druge strane dopušteno je da neki laici privremenim odabirom obavljaju službu čitača ili pak akolita kao izvanredni djelitelji pričesti. ${ }^{26}$ Što to znači? Nije isto biti (postavljeni) čitač i tek obavljati službu čitača jer je ovo drugo - bar načelno - privremeno, ad hoc, odnosno privremenim odabirom, latinski temporanea deputatione. Jednako tako biti postavljeni akolit koji po svojoj službi, kada god je potrebno, može svećeniku pomoći dijeliti pričest nije isto što i biti izvanredni djelitelj pričesti, dakle službenik ad hoc, uzet privremenim odabirom (na što upućuje i sam termin izvanredni). Evo primjera: pretpostavimo da je neki naš vjeroučitelj završio gimnaziju u Njemačkoj, a kod nas studij teologije. Jasno je da on savršeno govori njemački. Ako u školi nastavnik njemačkoga ode na bolovanje, taj ga vjeroučitelj može, naravno, izvrsno zamijeniti u nastavi. Međutim za naše ministarstvo on bi bio tek nestručna zamjena, bez obzira što on vjerojatno bolje govori njemački od spomenutoga nastavnika. Naš vjeroučitelj nije profesor njemačkoga. Tako je i s našim laicima koji čitaju čitanja na misi, ali nisu čitači, a isto je tako i s onim laicima koji obavljaju službu akolite (kao ministranti i izvanredni djelitelji pričesti), ali nisu akoliti. Tako imamo situaciju da je (postavljena) služba lektora i danas de facto tek stupanj na putu prema svećeništvu, dok u isto vrijeme privremenom odredbom naši laici čitaju u crkvi, iako većina njih uopće nije u toj službi privremeno. Sve se više u liturgiju uvode ad hoc službe, odnosno one privremenim odabirom. To je započelo još prije sabora. Tako zadnje prijesaborsko izdanje, ono iz 1962. godine, kaže da u pjevanim misama poslanicu može pjevati poslužitelj (ministrans - 'poslužitelj'), ne spominjući lektora. Valja jasno reći: nije svojstveno katoličkoj liturgiji da privremeni službenici de facto postanu stalni. U tradiciji Crkve toga nikada nije bilo.

Opća uredba Rimskoga misala navodi ove liturgijske službe: poslužitelj kod oltara koji zamjenjuje akolitu, čitač, psalmist, pjevački zbor, zborovođa, sakristan, tumač, prikupljač darova, onaj koji dočekuje vjernike i raspoređuje mjesta te obredničar. Sve te službenike župnik ili upravitelj crkve može izabranim laicima povjeriti litur-

\footnotetext{
${ }^{25}$ Usp. Ti si Krist - za nas i za sve ljude. Izjave i odluke Druge biskupijske sinode dakovačke i srijemske, Đakovo, 2008., br. 248-266, ovdje 251.

${ }^{26}$ Važeći Zakonik Kanonskoga prava kan. 230 \$ kaže: »Laici mogu na temelju privremene odredbe (ex temporanea deputatione) vršiti službu čitača u bogoslužnim činima... « Usp. Zakonik kanonskoga prava proglašen vlašću pape Ivana Pavla II., Zagreb, 1998.
} 
gijskim blagoslovom. ${ }^{27}$ Napomenimo da je u tradiciji Crkve apsolutna novina da župnici ili upravitelji crkava stvaraju i uvode nove obrede. Po naravi stvari samo je biskup onaj koji ima uređivati bogoslužje u svojoj biskupiji! Prema tomu, iako načelno - župnik može liturgijskim činom - koji bi sam pripravio - uvesti vjernike u određene službe, bilo bi, ipak, mnogo uputnije da se na razini biskupije - u nepostojećem vlastitom obredniku! - priprave odgovarajući obredi uvođenja u spomenute službe uz popratni pravilnik koji bi uređivao kome i pod kojim uvjetima se te službe mogu podijeliti. ${ }^{28}$

\section{Zaključak}

Navještaj Božje riječi sastavan je dio kršćanskoga bogoslužja u kojem se naviještena riječ uprisutnjuje i ostvaruje u otajstvenim znakovima. U bogoslužju su uvijek prisutni riječ i čin. Tako Crkva u euharistijskom slavlju vidi dva stola: stol riječi i stol tijela i krvi. Upravo zbog toga obnovljena liturgija Drugog vatikanskoga sabora inzistira da u svakom bogoslužnom činu bude uključena i služba riječi. Zbog toga je i služba čitača izuzetno važna u bogoslužju.

Služba čitača bila je u Crkvi od samih početaka, a ponovnu važnost dobila je uvođenjem narodnoga jezika u bogoslužje. Za tu službu potrebna je daljnja i bliža priprava, a i jedna i druga imaju u sebi dva vida: teološko-liturgijski i praktični. Čitači trebaju imati određenu teološku kulturu, što se može postići određenim tečajevi$\mathrm{ma}$, ali u isto vrijeme trebaju svladati određene vještine javnoga nastupa i čitanja u javnosti, imajući uvijek u vidu da naviještaju živu Božju riječ, Božji govor upućen zajednici.

Nažalost, na razini opće Crkve nije do kraja uređeno pitanje postavljenih čitača i onih koji privremenim odabirom preuzimaju tu službu. Kako god bilo, trebamo se nadati da će se Božja riječ u bogoslužju naviještati sve dostojnije i prikladnije da bi doprla do srca vjernika jer: »Živa je Riječ Božja i djelotvorna « (Heb 4, 12), i u početcima Crkve i danas.

${ }^{27}$ Usp. Opća uredba Rimskog misala, Zagreb, 2004., br. 100-107.

${ }^{28}$ U međuvremenu se objavljuju liturgijski predlošci primanja u neke službe, pripravljeni u kućnoj radinosti. Slično se mogu naći i predlošci primanja među kandidate za prvu pričest ili za krizmu i druga slična bogoslužja. Sve bi to moglo naći mjesta u Vlastitom obredniku. 


\title{
THE PREPARATION OF READERS FOR THE PROCLAMATION OF THE WORD OF GOD
}

\author{
Zvonko PAŽIN*
}

Summary: In the first part, the author points out that the proclamation of the Word of God is an integral part of the liturgy in which the word and act are mysteriously realized. That is why, in the Church, the ministry of the reader has been established from the beginning. Over the centuries, this ministry has been taken over by ordained ministers. After the liturgical reform - with the arrival of the vernacular in liturgy - readers were reintroduced. The author then talks about remote and immediate preparation of readers for the proclamation of the Word of God in liturgy. Remote preparation would consist of theological-liturgical elements and practical reading exercises. A $>$ non-academic $\ll$ method of preparation is proposed, consisting of seminars and exercises based on prepared materials, which would regularly occur at a higher than parish level. Immediate preparation would be a weekly meeting of readers consisting of an exegetical introduction to individual readings followed by a reading exercise according to certain rules. In the end, the author discusses the unresolved issues in the general Church regarding the instituted readers and readers by temporary deputation (temporanea deputatione), since, in practice, only candidates for the priesthood are regularly introduced into the instituted ministry of the reader, while - legally speaking - readers by temporary deputation are people who have been carrying out this ministry for years.

Keywords: proclamation of the Word of God, liturgical readers, Eucharist, preparation for the proclamation of the Word of God, temporanea deputatione ministries.

\footnotetext{
* Full Prof. Zvonko Pažin, Ph. D., Catholic Faculty of Theology in Đakovo, J. J. Strossmayer University of Osijek, Petra Preradovića St 17, P. O. box 54, Đakovo, Croatia, zvonko.pazin@os.t-com.hr
} 